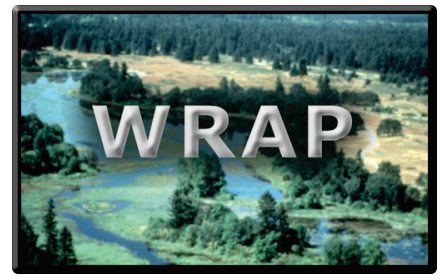

\title{
User Guide for Automated Wetland Determination Data Sheets
}

\author{
by Nathan T. Schulz and Jacob F. Berkowitz
}

PURPOSE: The U.S. Army Corps of Engineers (USACE) Wetland Delineation Manual and associated regional supplements require the completion of wetland determination data sheets to document the presence of wetlands and delineate wetland boundaries. Recently, the USACE developed Automated Wetland Determination Data Sheets (ADS) for each region of the country to assist users with document review, improvement of accuracy, and to increase efficiency. The following user guide provides instruction for application of the ADS which automatically populates hydrology, vegetation and soil indicators based upon data collected as part of a wetland determination.

DISCLAIMER: This document describes the proper usage of ADS developed by the USACE Regulatory Program to assist users in producing "data-entered" copies of the wetland determination data. As a result, it is the responsibility of the user to verify the accuracy of ADS results and understand that usage of the ADS is fully at your own risk.

INTRODUCTION: Wetland delineation remains fundamental to the USACE and the Environmental Protection Agency (EPA), with regulatory responsibilities under Federal regulations (33 CFR 320330), Section 404 of the Clean Water Act (CWA). Wetland delineation consists of standardized procedures for identification of wetlands and their boundaries to define the limits of Federal jurisdiction under the CWA. The Corps of Engineers Wetlands Delineation Manual (Corps Manual; Environmental Laboratory 1987) and associated regional supplements contain indicators and methodologies for delineating wetlands and data sheets for documenting site conditions (Berkowitz 2011 ; 2011b). Wetland determination data sheets have evolved over time as scientists expand the pool of knowledge concerning wetlands in the United States (Berkowitz 2012). The development of ADS provides improved technical support to regulatory staff and wetland delineation practitioners.

BACKGROUND: The data sheets associated with the USACE Manual (1987) and the regional supplements were originally released as Portable Document Format (PDF) files that could be printed and filled in by hand in a field setting. Over time, a number of data sheet formats have been developed by agency staff and others including fillable Adobe ${ }^{\circledR}$ PDF and Microsoft Word ${ }^{\circledR}$ files, as well as partially automated PDF and Microsoft Excel ${ }^{\circledR}$ files. The Engineer Research and Development Center (ERDC) in collaboration with the USACE Detroit District developed a set of ADS for each regional supplement. The ADS have identical layouts to the wetland delineation sheets found within each regional supplement. The ADS can be found at the USACE Regulatory Headquarters website (http://www.usace.army.mil/Missions/CivilWorks/RegulatoryProgramandPermits/reg_supp.aspx). The ADS include plant information from the USACE 2016 National Wetland Plant List (NWPL) (Version 3.3 or most current; http://rsgisias.crrel.usace.army.mil/NWPL/; Lichvar et al., 2016) and plant information from the United States Department of Agriculture (USDA) PLANTS Database (http://plants.usda.gov/index.html). The ADS use soil indicators from the National Resources Conservation Service (NRCS) Field Indicators of Hydric Soils (Version 8.0 or most current; 
http://www.nrcs.usda.gov/Internet/FSE_DOCUMENTS/nrcs142p2 053171.pdf; USDA-NRCS 2016). The following sections provide information regarding: 1) ADS data entry, 2) site information, 3) indicators of wetland hydrology, 4) hydrophytic vegetation, and 5) hydric soils.

DATA ENTRY: The ADS contain a number of lines of code (macros) that are not visible to the user. As a result, it is important that users open a fresh copy of the Excel ${ }^{\circledR}$ file for every use and ensure that macros are enabled. Deleting or overwriting lines of code prevents the ADS from functioning as intended. Therefore, using a fresh copy of the file ensures that all code will be preserved for future use. Users should select "Undo" if corrections are required and avoid using the delete key to maintain all code and associated formulas. There are three methods to enter data into the ADS: 1) selection/deselection of indicators and yes/no questions is accomplished by double-clicking cells, resulting in generation of an "X"; 2) drop down menus are utilized when users are required to select from a predetermined list of options; 3) manual data entry is required in all other cells. Table 1 provides an explanation of the symbols used throughout the ADS.

\begin{tabular}{|c|l|}
\hline \multicolumn{2}{|c|}{ Table 1. Explanation of ADS symbols. } \\
\hline \hline Symbol & Description \\
\hline \hline X & $\begin{array}{l}\text { Affirmative response to yes/no questions; documents the presence indicators of hydrophytic } \\
\text { vegetation, hydric soils, or wetland hydrology. }\end{array}$ \\
\hline$? C$ & $\begin{array}{l}\text { Denotes that an indicator may be present. Users should read the comment contained in the cell to } \\
\text { verify if the indicator is present. If present the indicator is confirmed by double-clicking the cell. }\end{array}$ \\
\hline & $\begin{array}{l}\text { Denotes that an indicator of hydric soils may be present based upon a combination of layers. The } \\
\text { commonly combined indicators reviewed by the ADS are Sandy Redox (S5), Dark Surface (S7), } \\
\text { Loamy Mucky Mineral (F1), Depleted Matrix (F3), Redox Dark Surface (F6), and Depleted Dark } \\
\text { Surface (S7). Users should read the comment contained in the cell to verify if the indicator is } \\
\text { present; the indicator is confirmed by double-clicking the cell. }\end{array}$ \\
\hline & $\begin{array}{l}\text { A red triangle indicates that a comment is present within the cell. Informative and instructional } \\
\text { comments are located throughout the ADS, which are displayed when the cursor is placed over cells } \\
\text { containing the triangle. }\end{array}$ \\
\hline & $\begin{array}{l}\text { A yellow background identifies cells that contain important information required for the ADS to } \\
\text { perform calculations. }\end{array}$ \\
\hline & $\begin{array}{l}\text { A red background identifies cells with incorrect formatting. Formatting must be corrected for the ADS } \\
\text { to perform calculations. }\end{array}$ \\
\hline
\end{tabular}

SITE INFORMATION: Input the requested sample area data at the top of page 1 of the ADS, including the project title, location, date, landscape position, and other background information. The sample point information will automatically be copied throughout the subsequent pages. Utilize the drop-down menus to select the appropriate state and sub-region [Land Resource Region (LRR)/Major Land Resource Area (MLRA)]. The ADS utilize the correct list of hydric soil indicators and hydrophytic vegetation indicator status based upon the state and sub-region selected. A map and descriptions of the LRR/MLRAs is available from the USDA-NRCS (2006) (www.nrcs.usda.gov/Internet/FSE_DOCUMENTS/nrcs 142p2 050898.pdf). Identify if the site visit sample areas vegetation, soil, or hydrology has been disturbed or naturally problematic by placing an 
" $\mathrm{X}$ " in the appropriate field, allowing for application of certain vegetation and soil indicators. If the sample area is not disturbed or problematic this section should be left blank.

Indicate whether "Normal Circumstances" are present by selecting "Yes" or "No." The ADS will complete the "SUMMARY OF FINDINGS" section based upon user inputs.

INDICATORS OF WETLAND HYDROLOGY: The ADS automatically generate a number of the indicators of wetland hydrology based upon user inputs (Table 2). For example, hydrology indicators including A1-surface water and A2-high water table will be automatically selected based upon field observations recorded on the ADS. Additional wetland hydrology indicators will be automatically selected based upon data entered within the vegetation (e.g., D5-FAC neutral test) and soils (e.g., $\mathrm{C} 1$-hydrogen sulfide odor) portions of the ADS. In all cases, each wetland hydrology indicator should be reviewed based upon user observations and selected if present.

\begin{tabular}{|c|c|c|}
\hline $\begin{array}{l}\text { Wetland hydrology } \\
\text { indicator }\end{array}$ & Description (for most regions) & ADS action \\
\hline Surface Water (A1) & $\begin{array}{l}\text { This indicator consists of the direct, visual observation } \\
\text { of surface water (flooding or ponding) during a site } \\
\text { visit. }\end{array}$ & $\begin{array}{l}\text { "X" generated from Field } \\
\text { Observations in the } \\
\text { Hydrology section. }\end{array}$ \\
\hline $\begin{array}{l}\text { High Water Table } \\
\text { (A2) }\end{array}$ & $\begin{array}{l}\text { This indicator consists of the direct, visual observation } \\
\text { of the water Table } 12 \text { inches }(30 \mathrm{~cm}) \text { or less below the } \\
\text { surface in a soil pit, auger hole or shallow monitoring } \\
\text { well. This indicator includes water tables derived from } \\
\text { perched water, throughflow, and discharging } \\
\text { groundwater (e.g., in seeps) that may be moving } \\
\text { laterally near the soil surface. }\end{array}$ & $\begin{array}{l}\text { "X" generated from Field } \\
\text { Observations in the } \\
\text { Hydrology section. }\end{array}$ \\
\hline Saturation (A3) & $\begin{array}{l}\text { Visual observation of saturated soil conditions } 12 \text { inches } \\
(30 \mathrm{~cm}) \text { or less from the soil surface as indicated by } \\
\text { water glistening on the surfaces and broken interior } \\
\text { faces of soil samples removed from the pit or auger hole. } \\
\text { This indicator must be associated with an existing water } \\
\text { table located immediately below the saturated zone; } \\
\text { however, this requirement is waived under episaturated } \\
\text { conditions if there is a restrictive soil layer or bedrock } \\
\text { within } 12 \text { inches }(30 \mathrm{~cm}) \text { of the surface. }\end{array}$ & $\begin{array}{l}\text { "X" generated from Field } \\
\text { Observations in the } \\
\text { Hydrology section and } \\
\text { Restrictive Layer in the Soil } \\
\text { section. }\end{array}$ \\
\hline $\begin{array}{l}\text { Sparsely Vegetated } \\
\text { Concave Surface } \\
\text { (B8) }\end{array}$ & $\begin{array}{l}\text { On concave land surfaces (e.g., depressions and } \\
\text { swales), the ground surface is either unvegetated or } \\
\text { sparsely vegetated (less than } 5 \text { percent ground cover) } \\
\text { due to long-duration ponding during the growing } \\
\text { season. }\end{array}$ & $\begin{array}{l}\text { "?" generated from \% Bare } \\
\text { Ground in Herb Stratum (if } \\
\text { present on sheet), or other } \\
\text { vegetation information in the } \\
\text { Vegetation section. }\end{array}$ \\
\hline Biotic Crust (B12) & $\begin{array}{l}\text { This indicator includes ponding-remnant biotic crusts, } \\
\text { benthic microflora, and the dried remains of free- } \\
\text { floating algae left on or near the soil surface after } \\
\text { dewatering. }\end{array}$ & $\begin{array}{l}\text { "?" generated from \% Cover } \\
\text { of Biotic Crust in the } \\
\text { Vegetation section. }\end{array}$ \\
\hline
\end{tabular}


ERDC/TN WRAP-17-1

July 2017

\begin{tabular}{|c|c|c|}
\hline $\begin{array}{l}\text { Wetland hydrology } \\
\text { indicator }\end{array}$ & Description (for most regions) & ADS action \\
\hline $\begin{array}{l}\text { Hydrogen Sulfide } \\
\text { Odor (C1) }\end{array}$ & $\begin{array}{l}\text { A hydrogen sulfide (rotten egg) odor within } 12 \text { inches } \\
(30 \mathrm{~cm}) \text { of the soil surface. }\end{array}$ & $\begin{array}{l}\text { "X" generated if Hydric Soil } \\
\text { Indicator Hydrogen Sulfide } \\
\text { (A4) has been checked with } \\
\text { an "X". }\end{array}$ \\
\hline $\begin{array}{l}\text { Dry-Season Water } \\
\text { Table (C2) }\end{array}$ & $\begin{array}{l}\text { Visual observation of the water table between } 12 \text { and } \\
24 \text { inches }(30 \text { and } 60 \mathrm{~cm}) \text { below the surface during the } \\
\text { normal dry season or during a drier-than-normal year. }\end{array}$ & $\begin{array}{l}\text { "?" generated from Field } \\
\text { Observations in the } \\
\text { Hydrology section. }\end{array}$ \\
\hline $\begin{array}{l}\text { Presence of Reduced } \\
\text { Iron (C4) }\end{array}$ & $\begin{array}{l}\text { Presence of a layer containing reduced (ferrous) iron in } \\
\text { the upper } 12 \text { inches }(30 \mathrm{~cm}) \text { of the soil profile, as } \\
\text { indicated by a ferrous iron test or by the presence of a } \\
\text { soil that changes color upon exposure to the air. }\end{array}$ & $\begin{array}{l}\text { "X" generated from Profile } \\
\text { Description in the Soil } \\
\text { section. }\end{array}$ \\
\hline $\begin{array}{l}\text { Thin Muck Surface } \\
\text { (C7) }\end{array}$ & $\begin{array}{l}\text { This indicator consists of a layer of muck } 1 \text { inch }(2.5 \\
\mathrm{cm} \text { ) or less thick on the soil surface. }\end{array}$ & $\begin{array}{l}\text { "X" generated from Profile } \\
\text { Description in the Soil } \\
\text { section. }\end{array}$ \\
\hline $\begin{array}{l}\text { Shallow Aquitard } \\
\text { (D3) }\end{array}$ & $\begin{array}{l}\text { This indicator occurs in and around the margins of } \\
\text { depressions and in flat landscapes, and consists of the } \\
\text { presence of an aquitard within } 24 \text { inches }(60 \mathrm{~cm}) \text { of } \\
\text { the soil surface that is potentially capable of perching } \\
\text { water within } 12 \text { in. }(30 \mathrm{~cm}) \text { of the surface. }\end{array}$ & $\begin{array}{l}\text { In most regions, "?" } \\
\text { generated from Restrictive } \\
\text { Layer data in the Soil } \\
\text { section. } \\
\\
\text { In the Northcentral and } \\
\text { Northeast Region, Alaska } \\
\text { Region, and Western } \\
\text { Mountains, Valleys, and } \\
\text { Coast Region, "X" generated } \\
\text { if Surface Water (A1) or High } \\
\text { Water Table (A2) are also } \\
\text { present. }\end{array}$ \\
\hline FAC-Neutral Test (D5) & The plant community passes the FAC-neutral test. & $\begin{array}{l}\text { "X" generated from } \\
\text { information in the Vegetation } \\
\text { section. }\end{array}$ \\
\hline
\end{tabular}

INDICATORS OF HYDROPHYTIC VEGETATION: The ADS 1) determine the hydrophytic indicator status of each plant species, 2) select dominant species, and 3) calculate indicators of hydrophytic vegetation based upon user inputs. In regions that utilize both four and five strata vegetation sampling sheets, the user must identify which sheet is being used for data entry by selecting the buttons to the right of each Vegetation tab. Additionally, in regions utilizing the Rapid Test, a check box is provided to document application of the Rapid Test (i.e., no calculations required). For each strata, the plot size utilized should be identified. In order to complete the required calculations, each species name and absolute percent cover must be provided. There are three ways to enter species names into the ADS:

Scientific name: The scientific name can be entered in full. Additionally, an autocomplete dropdown list with common and scientific names is activated when data entry begins, facilitating 
spelling and selection of the correct scientific names (Figure 1). For example, if Schoenoplectus tabernaemontani is present, the user can enter the genus name (Schoenoplectus) and select the specific epithet name (tabernaemontani) from the drop down menu. The hydrophytic indicator status will be automatically populated on the ADS.

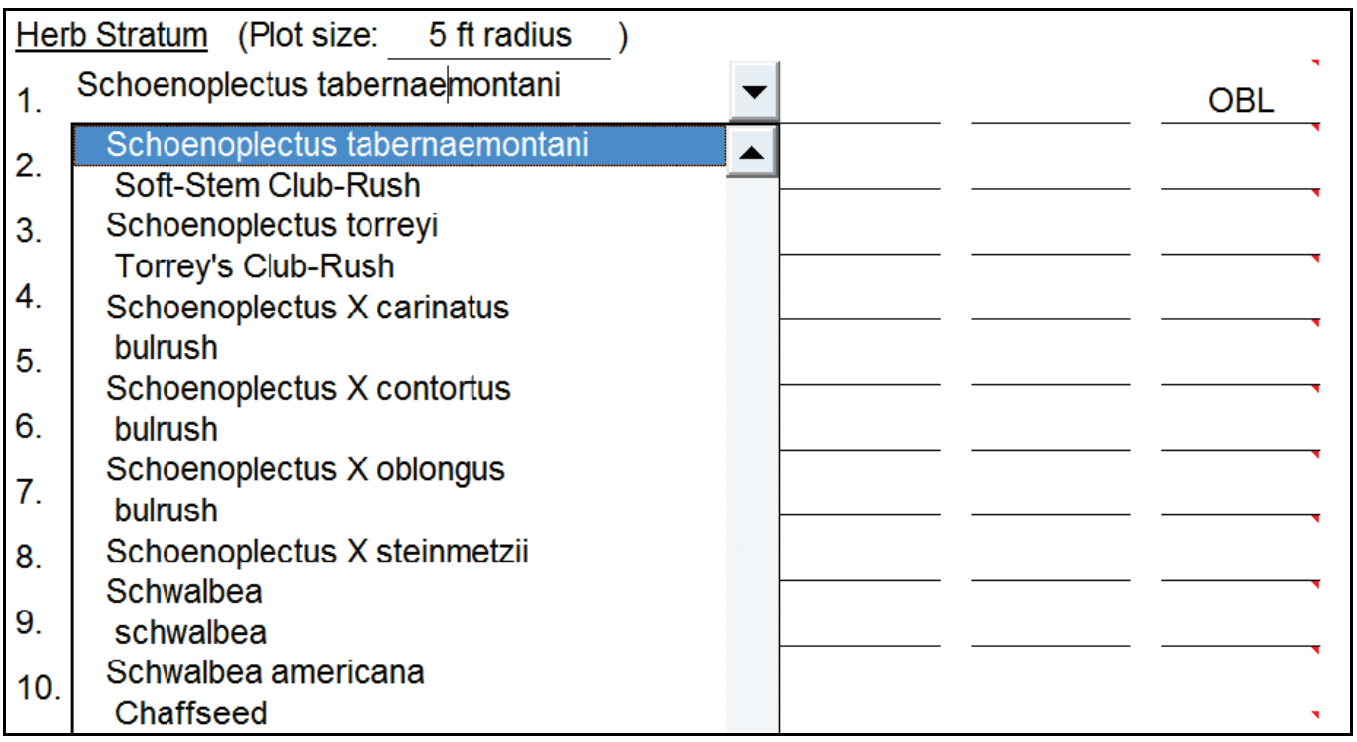

Figure 1. Example of species selection options for autocompleting scientific species names.

Common name: The common name can be entered by typing a "space" in the cell and then spelling out the common name (Figure 2). Once identified, select the scientific name directly above the common name from the list. For example if Schoenoplectus tabernaemontani is present but only the common name is known, the user can enter the common name "[space]Soft-Stem Club-Rush" and select the correct scientific name from the drop down menu. Once the correct scientific name is selected, the hydrophytic indicator status will be automatically populated on the ADS.

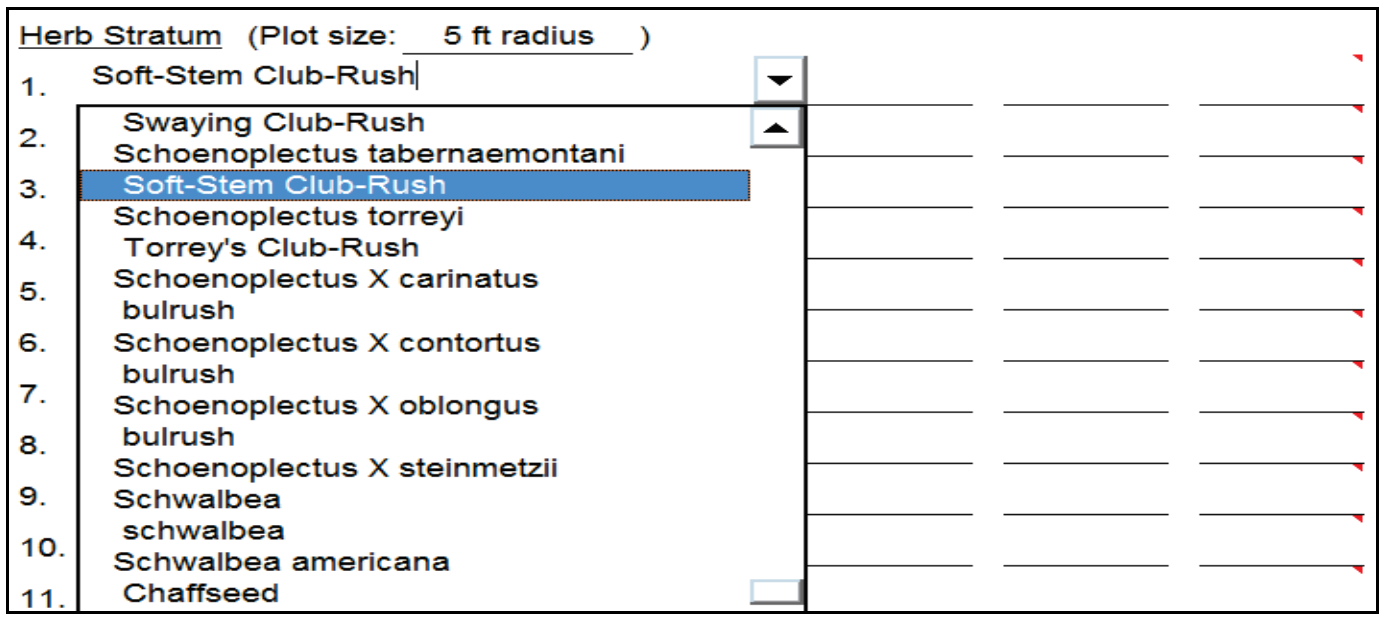

Figure 2. Example of searching common names by typing a "space" before entering the species name. 
Synonym name: Synonyms for the species can be entered and the correct hydrophytic indicator status will be generated. For example, if the plant Schoenoplectus tabernaemontani is present, the synonym Scirpus validus could be entered.

Based upon the species and the absolute percent cover data provided, the ADS determine which species are dominant and complete both the Dominance Test worksheet and the Prevalence Index worksheet. The Prevalence Index will be calculated, but will only be applied if wetland hydrology and hydric soil are present, or if those factors have been identified as disturbed or problematic. Additionally, a check box is provided if users do not want to display the results of the Prevalence Index when the Dominance Test has been met. The ADS will update the "Hydrophytic Vegetation Present" portion.

INDICATORS OF HYDRIC SOILS: The ADS will identify most hydric soil indicators based upon user inputs. However, due to the structure of several hydric soil indicators such as requiring identification of hydrogen sulfide odor or recognition of a spodic horizon a subset of hydric soil indicators remain un-automated (Table 3). As a result, each hydric soil indicator should be reviewed based upon user observations and selected if present. The hydric soil data should be entered into the ADS as displayed in Figure 3. Errors in data entry will generate an error statement or result in cell highlighted with a red background. The following section provides a step-by-step guide for entering hydric soil information. The ADS will automatically update the "Hydric Soil Present" portion.

\begin{tabular}{|l|l|l|}
\hline Table 3. Description of hydric soils with limited automation. \\
\hline \hline Hydric Soil Indicator & Description & Limitation \\
\hline \hline Hydrogen Sulfide (A4) & $\begin{array}{l}\text { A hydrogen sulfide odor starting at a depth } \leq 12 \text { inches } \\
\text { (30 cm) from the soil surface. }\end{array}$ & $\begin{array}{l}\text { The ADS cannot verify the } \\
\text { presence of hydrogen } \\
\text { sulfide odor. }\end{array}$ \\
\hline Organic Bodies (A6) & $\begin{array}{l}\text { Presence of 2 percent or more organic bodies of muck or } \\
\text { inches (15 cm) from the soil surface. }\end{array}$ & $\begin{array}{l}\text { The ADS cannot verify the } \\
\text { presence of organic } \\
\text { bodies. Only the } \\
\text { requirements for the } \\
\text { starting depth and the } \\
\text { presence of non- } \\
\text { automated remarks } \\
\text { made by the user for that } \\
\text { soil layer are verified. }\end{array}$ \\
\hline Polyvalue Below \\
Surface (S8)
\end{tabular}




\begin{tabular}{|c|c|c|}
\hline Hydric Soil Indicator & Description & Limitation \\
\hline $\begin{array}{l}\text { Thin Dark Surface } \\
\text { (S9) }\end{array}$ & $\begin{array}{l}\text { A layer } 2 \text { inches }(5 \mathrm{~cm}) \text { or more thick, starting at a depth } \leq 6 \\
\text { inches }(15 \mathrm{~cm}) \text { from the soil surface, with value of } 3 \text { or less } \\
\text { and chroma of } 1 \text { or less. At least } 70 \text { percent of the visible } \\
\text { soil particles must be masked with organic material, viewed } \\
\text { through a } 10 x \text { or } 15 x \text { hand lens. Observed without a hand } \\
\text { lens, the particles appear to be close to } 100 \text { percent } \\
\text { masked. This layer is underlain by a layer or layers with } \\
\text { value of } 4 \text { or less and chroma of } 1 \text { or less to a depth of } 12 \\
\text { inches }(30 \mathrm{~cm}) \text { or to the spodic horizon, whichever is less. }\end{array}$ & $\begin{array}{l}\text { The ADS cannot verify a } \\
\text { spodic horizon. Only the } \\
\text { requirements for the } \\
\text { upper layer and the value } \\
\text { and chroma for an } \\
\text { underlain layer are } \\
\text { verified. }\end{array}$ \\
\hline Reduced Vertic (F18) & $\begin{array}{l}\text { In Vertisols and Vertic intergrades, a positive reaction to } \\
\text { alpha-alpha-dipyridyl that: } \\
\text { a. Is the dominant ( } 60 \text { percent or more) condition of a } \\
\text { layer at least } 4 \text { inches }(10 \mathrm{~cm}) \text { thick starting at a depth } \\
\leq 12 \text { inches }(30 \mathrm{~cm}) \text {; or at least } 2 \text { inches }(5 \mathrm{~cm}) \text { thick } \\
\text { staring at a depth of } 6 \text { inches }(15 \mathrm{~cm}) \text { from the mineral or } \\
\text { muck soil surface, } \\
\text { b. Occurs for at least } 7 \text { continuous days and } 28 \\
\text { cumulative days, and } \\
\text { c. Occurs during a normal or drier season and month } \\
\text { (within } 16 \text { to } 84 \text { percent of probable precipitation). }\end{array}$ & $\begin{array}{l}\text { The ADS cannot verify the } \\
\text { reaction to alpha-alpha- } \\
\text { dipyridyl dye. Only the } \\
\text { thickness requirements } \\
\text { for the loamy/clayey or } \\
\text { muck texture are verified. }\end{array}$ \\
\hline Mesic Spodic (TA6) & $\begin{array}{l}\text { A layer } 2 \text { inches }(5 \mathrm{~cm}) \text { or more thick, starting at a depth } \leq 6 \\
\text { inches }(15 \mathrm{~cm}) \text { from the In Vertisols and Vertic intergrades, } \\
\text { a positive reaction to alpha-alpha-dipyridyl that: } \\
\text { a. Is the dominant ( } 60 \text { percent or more) condition of a } \\
\text { layer at least } 4 \text { inches }(10 \mathrm{~cm}) \text { thick starting at a depth } \\
\leq 12 \text { inches }(30 \mathrm{~cm}) \text {; or at least } 2 \text { inches }(5 \mathrm{~cm}) \text { thick } \\
\text { staring at a depth of } 6 \text { inches }(15 \mathrm{~cm}) \text { from the mineral or } \\
\text { muck soil surface, } \\
\text { b. Occurs for at least } 7 \text { continuous days and } 28 \\
\text { cumulative days, and } \\
\text { c. Occurs during a normal or drier season and month } \\
\text { (within } 16 \text { to } 84 \text { percent of probable precipitation). } \\
\text { mineral soil surface, that has value of } 3 \text { or less and } \\
\text { chroma of } 2 \text { or less and is underlain by either: } \\
\text { a. One or more layers } 3 \text { inches }(8 \mathrm{~cm}) \text { or more thick } \\
\text { occurring at a depth } \leq 12 \text { inches }(30 \mathrm{~cm}) \text { from the mineral } \\
\text { soil surface, having value and chroma of } 3 \text { or less, and } \\
\text { showing evidence of spodic development; or } \\
\text { b. One or more layers } 2 \text { inches }(5 \mathrm{~cm}) \text { or more thick } \\
\text { occurring at a depth } \leq 12 \text { inches }(30 \mathrm{~cm}) \text { from the mineral } \\
\text { soil surface, having value of } 4 \text { or more and chroma of } 2 \text { or } \\
\text { less, and directly underlain by a layer }(\mathrm{s}) 3 \text { inches }(8 \mathrm{~cm}) \text { or } \\
\text { more thick having value and chroma of } 3 \text { or less and } \\
\text { showing evidence of spodic development. }\end{array}$ & $\begin{array}{l} \\
\\
\text { The ADS cannot verify } \\
\text { spodic development. } \\
\text { However, all other } \\
\text { requirements are verified. } \\
\end{array}$ \\
\hline
\end{tabular}




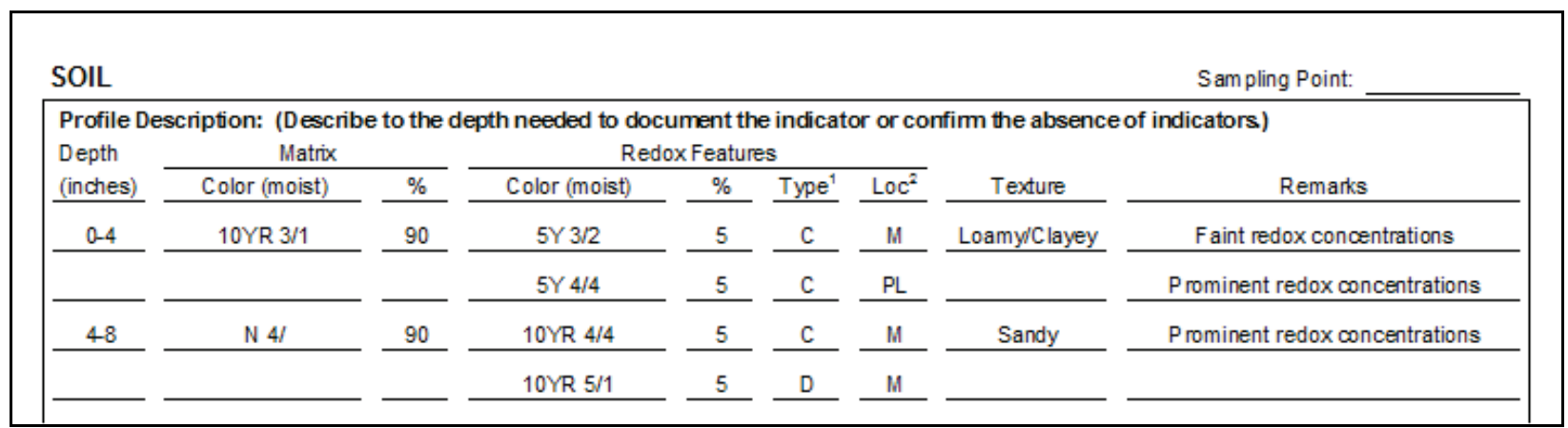

Figure 3. Example of the proper method of inputting soil data.

Depth: The depth of each layer is recorded in inches with starting and ending depths separated using a dash. The upper limit of each subsurface layer should match the lower limit of the layer above. Application of the ADS requires users to start at a depth of zero.

Soil color and contrast: Soil matrix and redox feature colors should be entered using the format hue[space]value/chroma (e.g., 10YR 3/1). Soil colors on the gley pages have the hue chromas ranging from zero to two. For example, soil colors with a neutral $(\mathrm{N})$ hue, value of 2.5 and chroma of zero are entered as hue[space]value/(blank) (e.g., N 2.5/). Although soil colors do exist between the chips provided in the Munsell color chart, the ADS is limited to the hue, value, and chroma designations provided on each color page. As a result, when colors occur between chips (e.g., chroma of 2+), hydric soil indicators should be reviewed and evaluated based upon user observations. The ADS determines the contrast between soil matrix and redox feature colors, reporting the results (prominent, distinct, faint) in the remarks section adjacent to each entry. Any additional remarks should be recorded in the "Remarks" section located below the list of hydric soil indicators. The abundance (\%) of the soil matrix and redox feature color(s) are entered manually and should add up to $100 \%$ for each layer examined.

Redox Feature and texture information: The remaining fields in the ADS soil section utilize drop-down menus to determine the redox feature type, location, and texture. The redox feature type drop-down menu includes selections for concentrations (C), depletions (D), reduced matrix (M), and masked sand grains (MS). The location ("Loc") field accounts for redox features observed in pore linings (PL), soil matrix (M), or a combination of locations (PL/M). Available texture designations include the mineral soils (loamy/clayey, sandy, mucky, loamy/clay, mucky sand) and the organic soils (peat, mucky peat, muck). Additional guidance on conducting soil descriptions and determining soil texture can be found within the regional supplements.

ADS hydric soil outputs: Based upon the soil profile provided, the ADS generates " $X$ " if a hydric soil indicator is present; "?" if the depth, color, and redox feature requirements are met but additional information (e.g., landscape position) must be verified by the user; or a "?C" if common hydric soil combinations are met (Table 1). The ADS also generates a "?" if an indicator for problematic hydric soils is present in sample areas with disturbed or problematic soils that display indicators of hydrophytic vegetation and wetland hydrology (or multiple factors are disturbed or problematic).

SUMMARY: The ADS provide a tool to increase technical accuracy and efficiency in the evaluation of wetland delineation data. Users should open a fresh copy each time the ADS is utilized, ensuring 
that all code remains intact. The ADS automatically populates many of the wetland hydrology, hydrophytic vegetation, and hydric soil indicators based upon data collected as part of a wetland delineation. The sections above provide information on appropriate data entry procedures and highlight the benefits and limitations of the ADS. Users are encouraged to review all guidance in the Corps Manual (1987) and regional supplements, including "Chapter 5: Difficult Wetland Situations", prior to making a final wetland delineation determination.

POINT OF CONTACT: For additional information on the application of the ADS or to submit bug reports email autodatasheet@usace.army.mil.

ACKNOWLEDGEMENTS: Funding for the development of ADS was provided by the Wetlands Regulatory Assistance Program. Dr. Tosin Sekoni, Aaron Damrill, and Steven Currie provided comments on a draft of the document. The authors would like to thank numerous USACE staff for valuable input on the ADS and this user guide.

\section{REFERENCES}

Berkowitz, J. F. 2011a. Regionalizing the Corps of Engineers wetland delineation manual: Process overview and status report. National Wetland Newsletter 33:24-28.

Berkowitz, J. F. 2011b. Recent advances in wetland delineation - implications and impact of regionalization. Wetlands 39(3):593-601

Berkowitz, J. F. 2012. Updating Regional Supplements to the Corps of Engineers Wetland Delineation Manual. ERDC TN-WRAP-12-1. Vicksburg, MS: U.S. Army Engineer Research and Development Center.

Environmental Laboratory. 1987. Corps of Engineers wetlands delineation manual. Technical Report Y-87-1. Vicksburg, MS: U.S. Army Engineer Waterways Experiment Station.

Lichvar, R. W., D. L. Banks, W. N. Kirchner, and N. C. Melvin. 2016. The National Wetland Plant List: 2016 wetland ratings. Phytoneuron 2016-30: 1--17.

United States Department of Agriculture - Natural Resources Conservation Service (USDA-NRCS). 2006. Land Resource Regions and Major Land Resource Areas of the United States, the Caribbean, and the Pacific Basin. U.S. Department of Agriculture Handbook 296. Washington DC.

United States Department of Agriculture - Natural Resources Conservation Service. 2016. Field indicators of hydric soils in the United States, Version 8.0. L. M. Vasilas, G. W. Hurt, and J. F. Berkowitz (eds.) USDA, NRCS, in cooperation with the National Technical Committee for Hydric Soils.

NOTE: The contents of this technical note are not to be used for advertising, publication, or promotional purposes. Citation of trade names does not constitute an official endorsement or approval of the use of such products. 